\title{
ANALYSIS OF MECHANICAL DEWATERING OF DIGESTATE
}

Krzysztof Mudryk ${ }^{*}$, Jarosław Frączek, Marcin Jewiarz, Marek Wróbel, Krzysztof Dziedzic

Department of Mechanical Engineering and Agrophysics, University of Agriculture in Krakow

"Corresponding author: e-mail: krzysztof.mudryk@ur.krakow.pl

\begin{tabular}{|c|c|}
\hline ARTICLE INFO & ABSTRACT \\
\hline $\begin{array}{l}\text { Article history: } \\
\text { Received: September } 2016 \\
\text { Received in the revised form: } \\
\text { November } 2016 \\
\text { Accepted: December } 2016 \\
\end{array}$ & $\begin{array}{l}\text { Technology of processing of agricultural raw material and production } \\
\text { residues from agri-food industry often requires their dewatering. } \\
\text { Digestate is one of such materials i.e. the mass remaining after the } \\
\text { bio-gasification process, which has great hydration (above } 85 \% \text { ). The } \\
\text { objective of the research was to know the impact of dewatering on the }\end{array}$ \\
\hline $\begin{array}{l}\text { Key words: } \\
\text { mechanical dewatering, } \\
\text { digestate, } \\
\text { screw press, } \\
\text { moisture }\end{array}$ & $\begin{array}{l}\text { change of water content in digestate from biogas in Piekoszów. } \\
\text { A mechanical dewatering process was carried out and reflected the } \\
\text { conditions of operation of screw presses for dewatering of plant raw } \\
\text { materials, whose screen internal diameter is } 160 \mathrm{~mm} \text {. Knowing the } \\
\text { impact of pressure on the dynamics of raw material moisture decrease } \\
\text { will allow modelling of the operation of industrial devices with similar } \\
\text { operation parameters. Thus, a research on the dewatering process with } \\
\text { the use of pressure within } 0.58-2.91 \mathrm{MPa} \text { and slotted screens with } \\
\text { meshes size of } 0.1 ; 0.2 \text { and } 0.3 \mathrm{~mm} \text { were carried out. The analysis of } \\
\text { the obtained results indicates that an effective process of dewatering } \\
\text { of the investigated digestate takes place at the working pressure to } \\
1.74 \mathrm{MPa} \text { regardless the applied screen. Further increase of pressure } \\
\text { does not cause a significant decrease of moisture in the investigated } \\
\text { material. }\end{array}$ \\
\hline
\end{tabular}

\section{Introduction}

Due to the increase of the number of biogas plants in Poland in recent years - from 8 in 2008 to 87 in 2016 (Ćwil, 2016) a considerable increase of the number of post-fermentation mass for management took place. Presently, resources of dry mass of digestate are 172 thousand tonnes annually. However, it should be emphasised that the post-fermentation mass in its primary form has a great content of moisture, which often exceeds $85 \%$. Thus, it is indispensable to develop proper dewatering technologies which would allow further use of post-fermentation mass e.g. for fertilization purposes. Mechanical processes of dewatering of materials were developed in order to effectively escort water not related permanently with material, in particular at a very high initial content of moisture (above $60 \%$ ). In the recent several years, technology of mechanical dewatering was the research object of scientists from Australia and Germany (Bergins, 2003; Bergins et al., 2007; Butler et al., 2008; Clayton et al., 2007; Fei et al., 2006; Hulston et al., 2005; Strauß et al., 1997; Vogt et al., 2012; Wheeler, 2009). Dewatering processes are carried out with the use of the pressure phenomenon as well as under conditions of raised temperature of the process 
amounting to $100-250^{\circ} \mathrm{C}$, due to which water will be removed by means of vaporization and impact of high pressure (Artanto and Chaffe, 2005; Clayton et al., 2006; Hulston et al., 2005). Mechanical dehydration processes of raw material have the greatest significance in case of dehydration of production residues in agri-food industry and in water purification sectors (dewatering of screenings and sludge).

Digestate is one of such materials, which is often subjected to dehydration processes. In the dewatering process of post-ferments, sludge water is produced in the amount of approx. $0.5 \mathrm{~m}^{3} \cdot \mathrm{Mg}^{-1}$ of the batch. It may be used as a liquid fertilizer in agriculture for hydration of compost prisms or purification in a sewage treatment plant.

As a part of the project related to the use of a fraction from bio-gasification in technologies which produce organic fertilizers, attempts to reduce the water content were made, amongst others, with mechanical technologies. For this purpose a screw press with a slotted screen with three dimensions was used: $0.1 ; 0.2$ and $0.3 \mathrm{~mm}$ (Fig. 1).

The initial research which was carried out proved that the use of a single dewatering process (one move through the screen system) does not ensure removal of satisfactory amount of water. Thus, a cascade manner of material dewatering was used in the research.
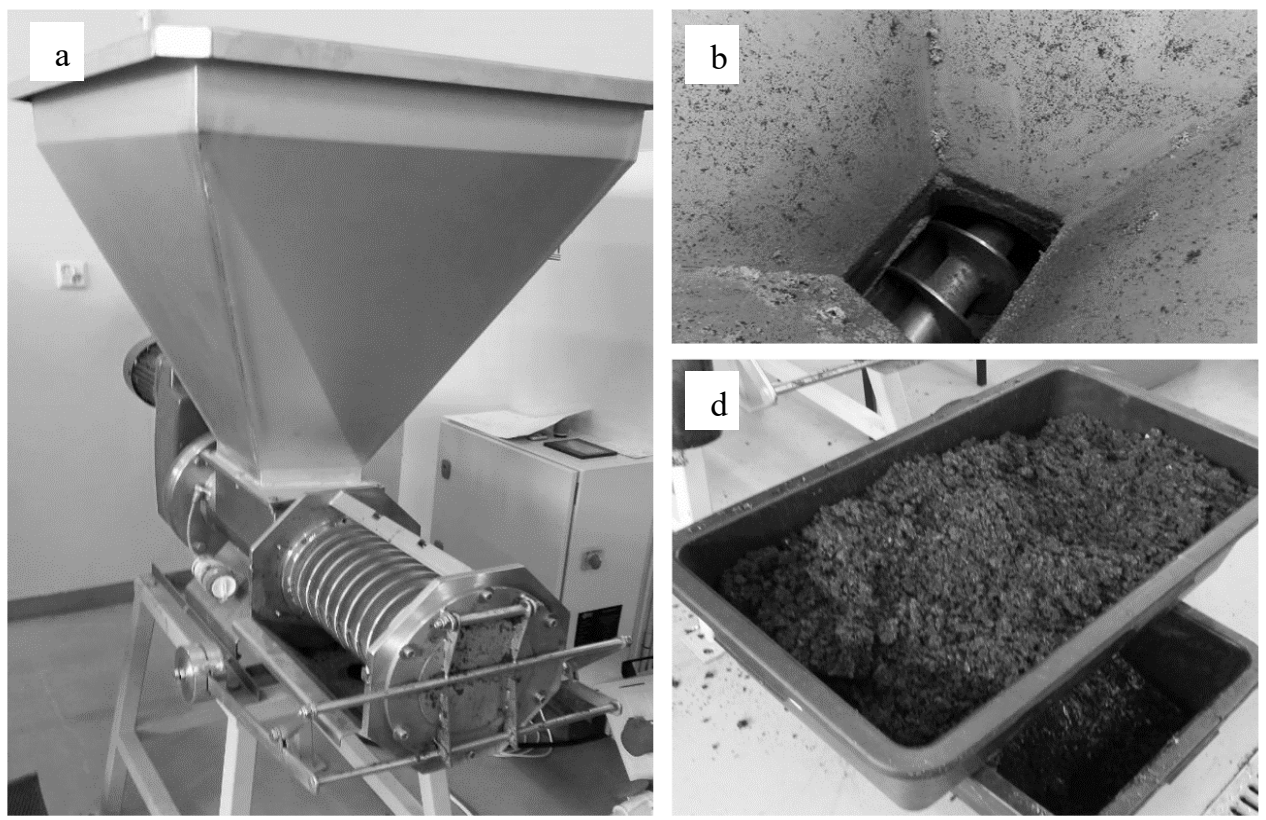

Figure 1. Screw press PFT160 by PFTechnology, a-general view, $b$-charging hopper with working screw, $c$-digestate after pressing process

Due to such approach, dewatering effectiveness in further movement of digestate through the device was determined. As it can be seen in figure 2, four-time passage of raw material through the dewatering system allows obtaining raw material moisture at the level of $78-79 \%$. During the above mentioned experiment, there were some obstacles related to 
Analysis of mechanical...

a detailed description of process parameters i.e. pressure, which occurred during dehydration.

Therefore, an attempt to design a test stand with a strength machine for dewatering of plant materials was made under conditions related to the ones occurring in the screw press.

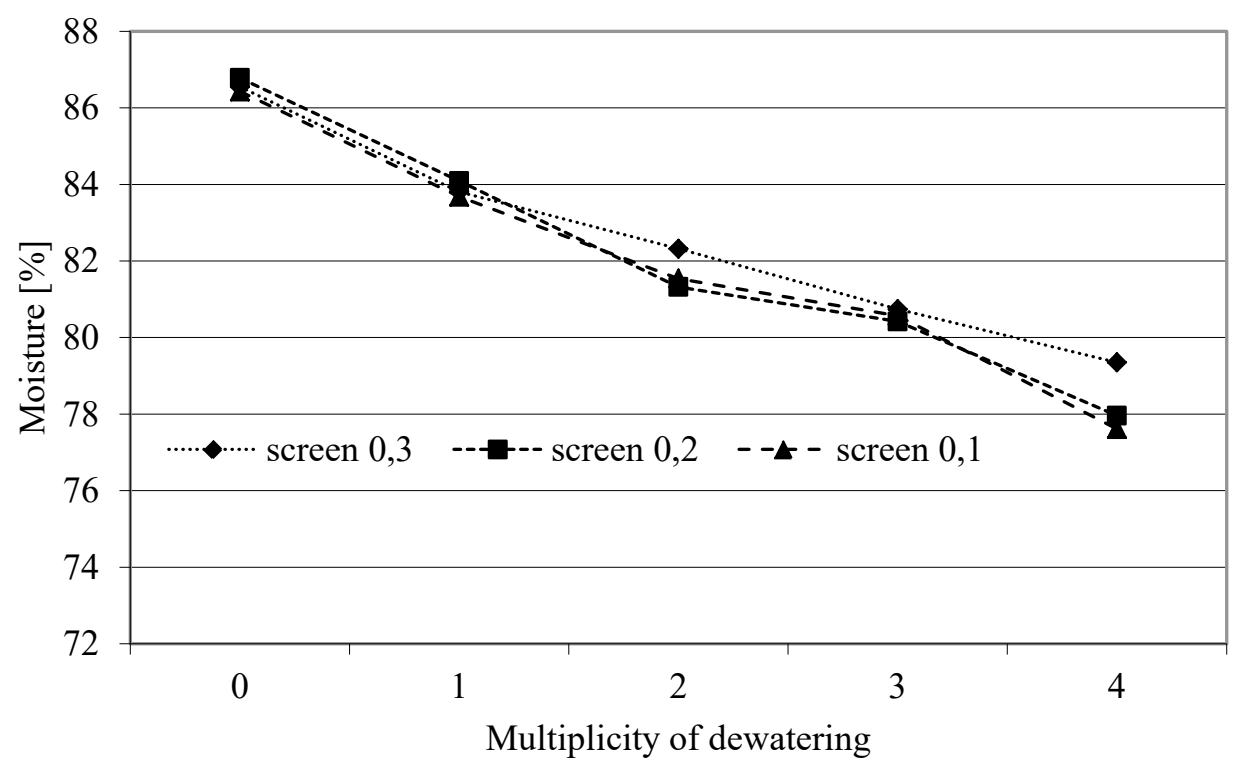

Figure 2. Changes in the moisture of digestate during cascade dewatering on the screw press

The objective of the research was to know the impact of dewatering on the change of water content in the digestate from biogas. Mechanical dehydration process was carried out reflecting the conditions of operation of screw presses for dewatering of plant raw materials, whose screen internal diameter is $160 \mathrm{~mm}$. Knowing the impact of pressure on the dynamics of raw material moisture decrease will allow modelling the operation of industrial devices with similar working parameters. The paper presents the research on the dewatering process with the use of pressure within 0.58-2.91 MPa and slotted screens with meshes size of $0.1 ; 0.2$ and $0.3 \mathrm{~mm}$.

\section{Material and methodology of research}

Post-ferment from Piekoszów biogas plant constituted research material. Fresh material had total moisture of $86.4 \%$. Before proper tests on the dewatering process are carried out, size distribution measurement was performed with the use of 8 screens with the following meshes dimensions: $3.15 ; 0.25 \mathrm{~mm}$. The experiments on mechanical dewatering were performed according to the schematic diagram presented in figure 3. 


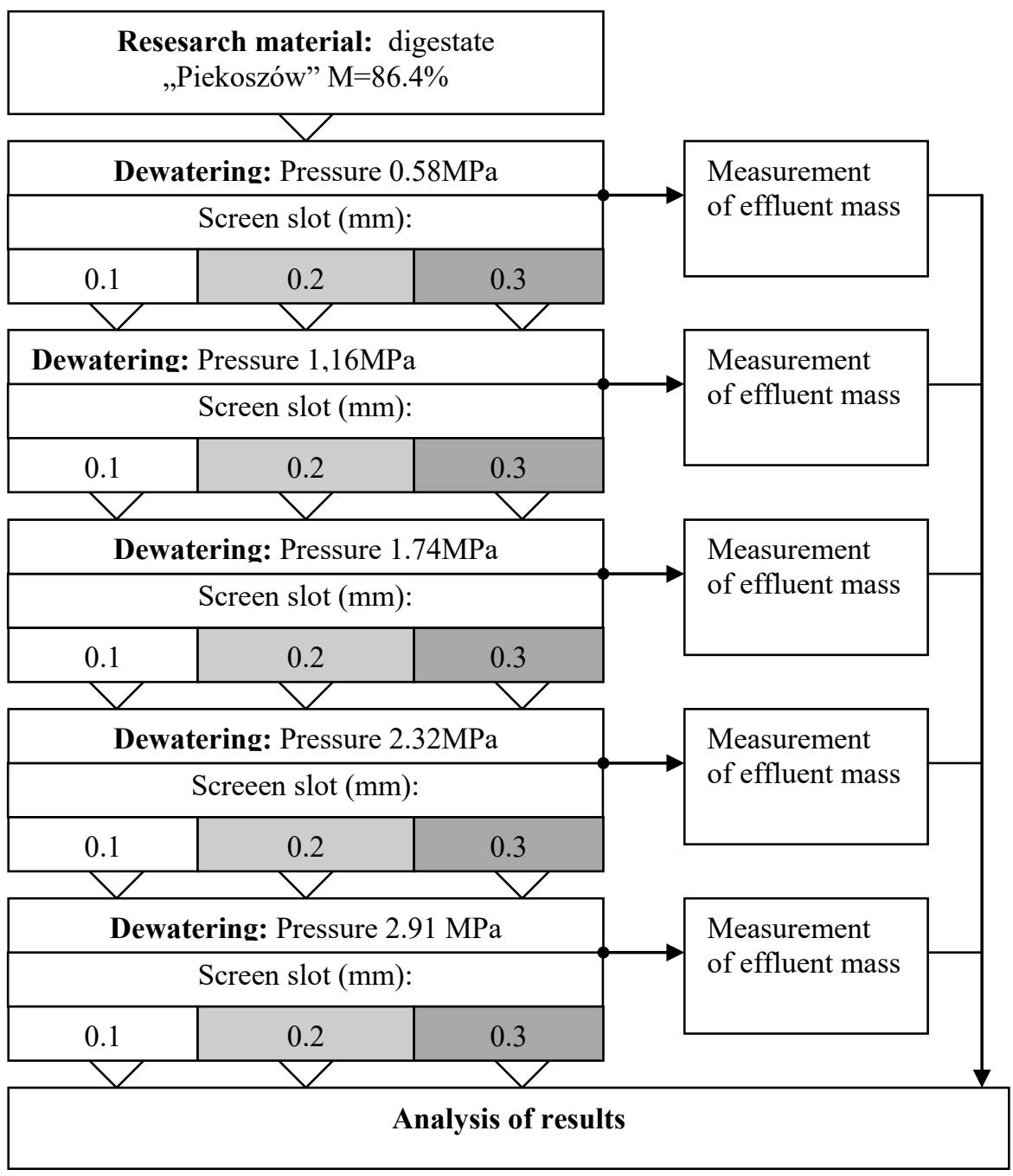

Figure 3. Diagram of research on digestate dehydration process

Research on the dewatering process of material was carried out with the use of EDZ 20 strength machine equipped with dewatering attachments comprising replaceable screens with a working slot of: $0.1 ; 0.2$ and $0.3 \mathrm{~mm}$ (Fig. 4). The remaining components of the attachment included a sample compacting piston (which causes dewatering) and a tank for effluent.

For each screen a dewatering test was carried out at a gradually increased dewatering pressure which was respectively: $0.58 ; 1.16 ; 1.74 ; 2.32$ and $2.91 \mathrm{MPa}$. Each level of pressure was maintained to the moment effluent ceased to be emitted. In the moment of its fading, pressure was increased to the value of the next level. The mass of the obtained 
Analysis of mechanical...

effluent at a given pressure was measured with the use of RADWAG scales with precision of $\pm 1 \mathrm{~g}$. Based on the initial moisture of a sample and effluent mass it was possible to determine the moisture level possible to be obtained at investigated dewatering pressures.
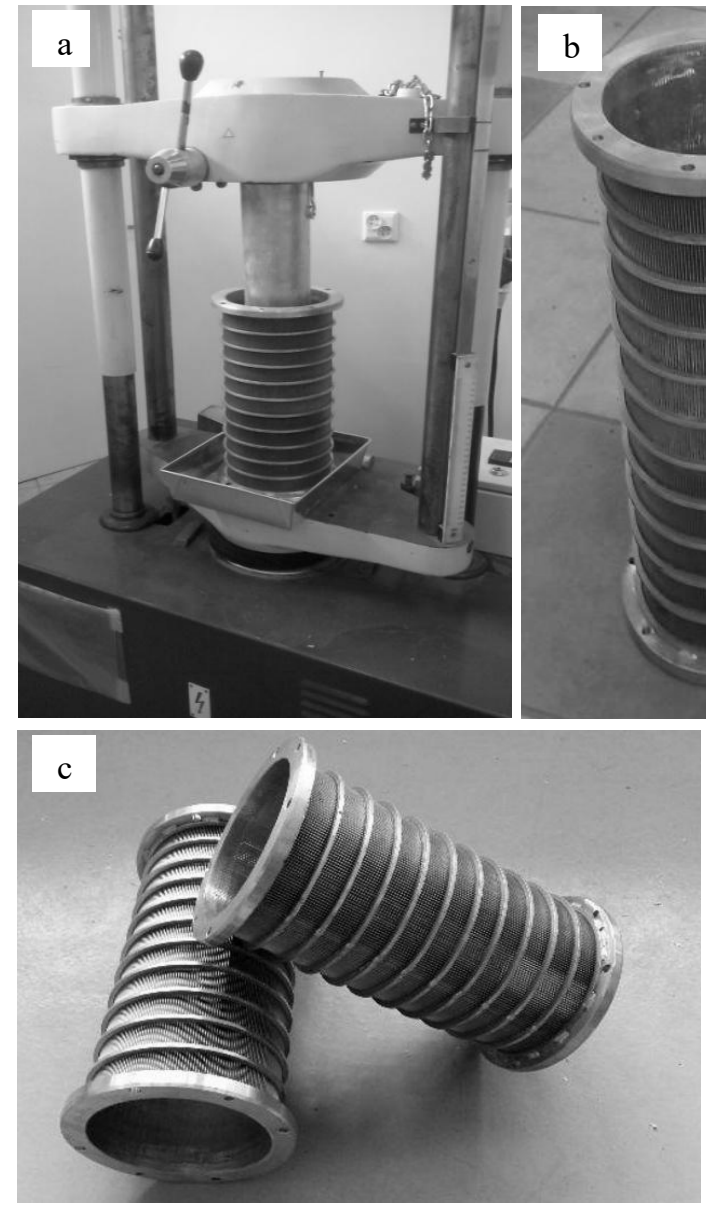
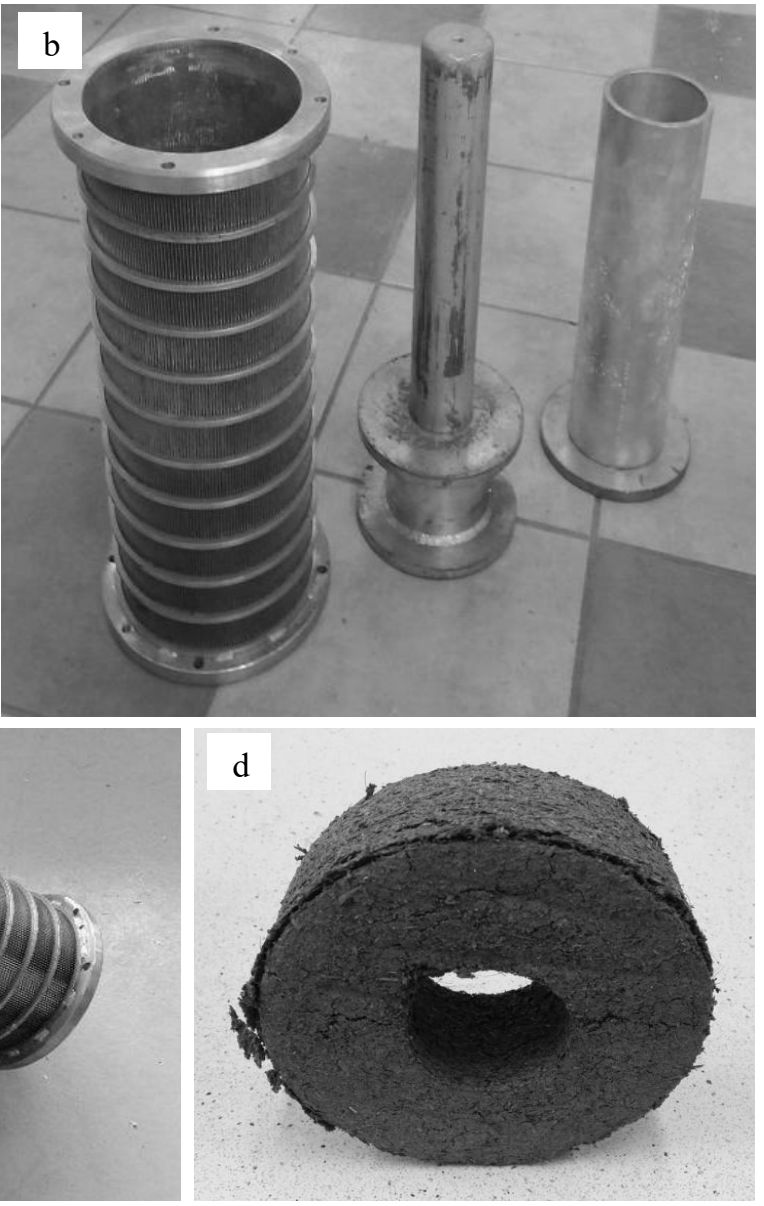

Figure 4. Research stand: a-general view, $b$ - components of compaction attachment $c$-screen, $d$-digestate sample after dehydration process

Samples prepared to the research of the dewatering process weighted 1.5 kilo. The sample mass was selected in such a way that its height during compaction (Fig. 4d) was close to the lead of winding of a working screw of the press (a space between the screw winding - Fig. 1b). 


\section{Research results}

The research which was carried out allowed determination of the course of changes of the dewatered digestate moisture in relation to the applied pressure.

The investigated digestate from biogas plant in Piekoszów, which according to producer's information resulted from the mixture of corn silage, manure and soft slaughter waste (inter alia, blood, bowels and stomach content) had particle size distribution presented in figure 5. Particles, which remained on the $1.4 \mathrm{~mm}$ screen were a dominant fraction and their participation in the mass was $26.4 \%$. Particles which remained on the $0.5 \mathrm{~mm}$ screen were the following fraction whose participation was considerable. Dust fractions below $0.25 \mathrm{~mm}$ were only $4.4 \%$ and the biggest fractions above $3.15 \mathrm{~mm}$ had approx. $8.6 \%$ of mass.

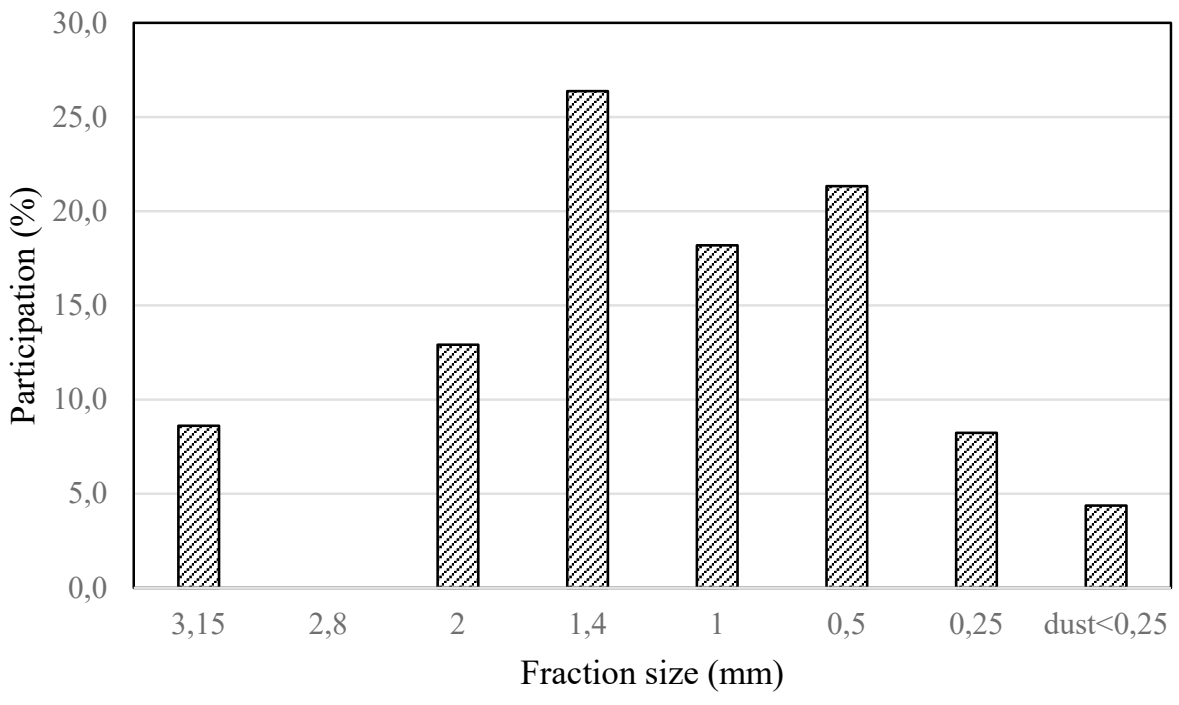

Figure 5. Particle size distribution of digestate

Post-ferment which was subjected to dewatering process had initial moisture at the level of $86.4 \%$. Following figures present changes in moisture and mass loss (effluent) in relation to pressure put on the dewatered substance with the use of three slotted screens with varied size of slots.

Figures 6 and 7 present results of the dewatering process with the use of a screen whose meshes are $0.3,0.2$ and $0.1 \mathrm{~mm}$. In case of digestate dewatering at the $0.3 \mathrm{~mm}$ screen, the recorded drop of moisture was less than $7.4 \%$. The highest dynamics of changes was reported in the initial dewatering period at the pressure of $1.74 \mathrm{MPa}$ (press force $30 \mathrm{kN}$ ). Further increase of dewatering pressure caused the decrease of the process dynamics and at the pressure increase from 2.32 to $2.91 \mathrm{MPa}$ mass loss was only $2.5 \%$ (Fig. 6). The course of the recorded changes in moisture was described mathematically with a third degree polynomial where the ratio of adjustment $\mathrm{R}^{2}$ was 0.98 . During digestate dewatering with 
Analysis of mechanical...

the use of a slotted screen $0.2 \mathrm{~mm}$, the course of moisture changes and mass loss was similar as in case of dewatering with a $0.3 \mathrm{~mm}$ screen. The recorded moisture drop was approx. $8.1 \%$ and was also described with a third-degree polynomial with adjustment of $\mathrm{R}^{2}$ equal to 0.99 .

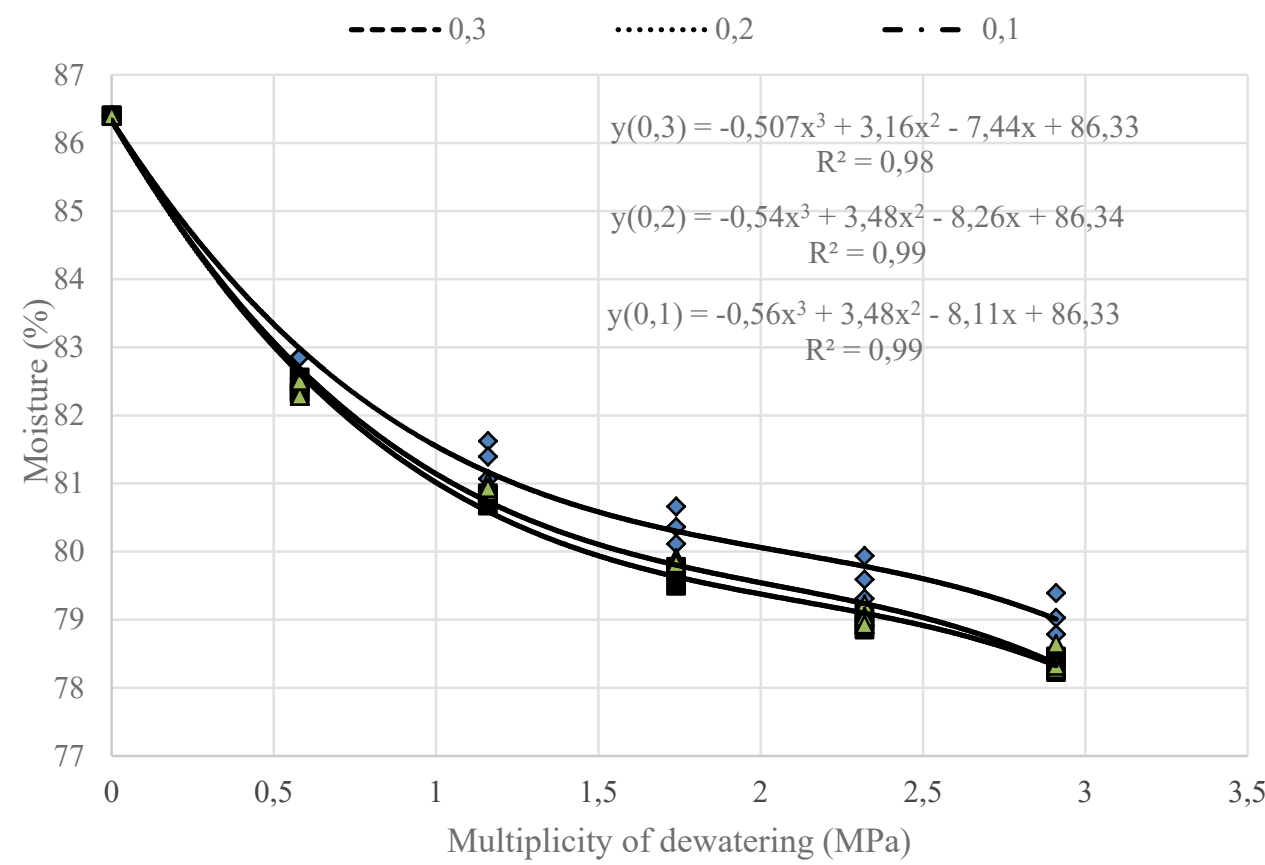

Figure 6. Relation of digestate moisture relation to dewatering pressure with the use of investigated screens

Similarly, in case of mass loss the highest dewatering dynamics was reported at the pressure increase to $1.74 \mathrm{MPa}$ (pressure $30 \mathrm{kN}$ ). Further increase of pressure caused decrease of the dynamics of loss of dewatered digestate loss. The increase of pressure from 2.32 to $2.91 \mathrm{MPa}$ (pressure from 40 to $50 \mathrm{kN}$ ) caused mass loss at the level of $2.6 \%$.

This mass loss is considerably low which makes us believe that further increase of pressure will not bring expected effects and energy consumption of the process may be very high. Similarly as with the use of the $0.3 \mathrm{~mm}$ screen, the course of changes in the mass loss in relation to pressure in the investigated range is presented the best by a power function for which adjustment ratio $\mathrm{R}^{2}$ is 0.99 .

Research results obtained for a screen with $0.1 \mathrm{~mm}$ slots are presented by moisture changes and changes in the dynamics of mass loss similarly as in the case with the $0.2 \mathrm{~mm}$ screen. A mathematical description of changes was presented with the use of a third-degree polynomial in case of moisture changes and a power function in case of changes in the biomass loss. 


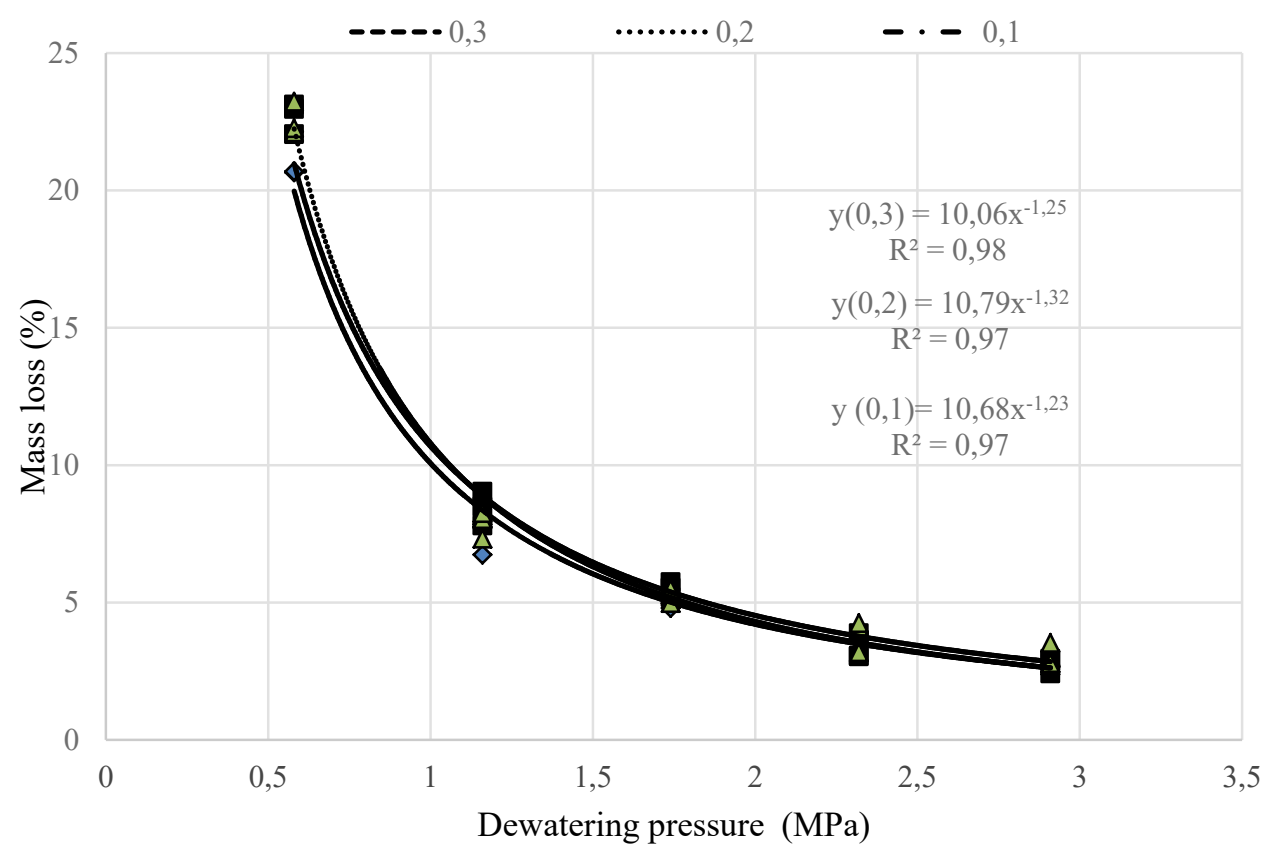

Figure 7. Relation of digestate mass loss from dewatering pressure

The statistical analysis of the results obtained in STATISTICA 12.3PL with the use of Kruskal-Wallis test proved that the digestate pressure dewatering process with a slotted screen with the dimensions of: $0.1 ; 0.2$ and $0.3 \mathrm{~mm}$ do not show significant differences in the course of the process.

Thus, it may be stated that the mechanical dewatering process should be carried out with the use of screens with the biggest size of slots $(0.3 \mathrm{~mm})$ which will be significant in maintenance works (e.g. cleaning of screens).

\section{Conclusion}

The research of the digestate mechanical dewatering allowed obtaining information on the moisture changes dynamics and its mass loss in relation to the applied pressure in the range of 0.58-2.91 $\mathrm{MPa}$. The analysis of the obtained results indicates that effective process of dewatering of the investigated digestate takes place at the working pressure to $1.74 \mathrm{MPa}$ regardless the applied screen. Further increase of pressure does not cause a significant decrease of moisture.

The obtained research results and opinions enable to better know the process of mechanical dewatering of highly-hydrated materials on the example of digestate and to provide verification information on the dewatering process on screw presses. Referring the obtained results of moisture changes to the ones recorded during cascade dewatering on the 
Analysis of mechanical...

screw press, it may be assumed that the use of pressure at the level of 2.91 MPa allows obtaining a similar dewatering effect as fourfold dewatering at the mentioned press.

Current results will be a basis for carrying out further research with the use of a screw press, which aim at optimization of the process with energy expenditures. Moreover, upon agreement with the producer of the device, works on the increase of efficiency of the dewatering process will be carried out (possible increase of the working pressure).

It should be also mentioned that further research will be indispensable for knowing and determination of conditions of operation of screw presses during the dewatering process (e.g. fruit, vegetables).

\section{Acknowledgement}

Research was funded by the National Centre for Research and Development and the National Fund for Environment Protection as a part of GEKON program - project no. GEKON1/05/214543/38/2015 "Proecology production of organic and mineral fertilizers based on waste: by -products of combustion and biogasification of biomass".

\section{References}

Artanto, Y., Chaffee A.L. (2005). Dewatering low rank coals by mechanical thermal expression (MTE) and its influence on organic carbon and inorganic removal. Coal Preparation, 25, 251-267.

Bergins, C. (2003). Kinetics and mechanism during mechanical/thermal dewatering of lignite. Fuel, 82(4), 355-364.

Bergins, C., Hulston, J., Strauss, K., Chaffee, A.L. (2007). Mechanical/thermal dewatering of lignite. Part 3: physical properties and pore structure of MTE product coals. Fuel, 86, 3-16.

Butler, C.J., Green, A.M., Chaffee, A.L. (2008). MTE water remediation using Loy Yang brown coal as a filter bed adsorbent. Fuel, 87, 894-904.

Clayton, S.A., Scholes, O.N., Hoadley, A.F.A., Wheeler, R.A., Mclntosh, M.J., Huynh D.Q. (2006). Dewatering of biomaterials by mechanical thermal expression. Drying Technology, 24, 819834.

Clayton, S.A., Wheeler, R.A., Hoadley, A.F.A. (2007). Pore destruction resulting from mechanical thermal expression. Drying Technology, 25(4), 533-546.

Ćwil M. Biogazownie rolnicze w Polsce, rynek obecny, perspektywy rozwoju. 2016 http://ahk.pl/fileadmin/ahk_polen/Erneuerbare_Energien/2016_06_Michal_Cwil_PIGEOR_bioga zownie.pdf

Fei, Y., Artanto, Y., Giroux, L., Marshall, M., Jackson, W.R., MacPhee, J.A., Charland, A.L., Chaffee, D.J. (2006). Allardice Comparison of some physico-chemical properties of Victorian lignite dewatered under non-evaporative conditions. Fuel, 85, 1987-1991.

Hulston, J., Favas, G., Chaffee, A.L. (2005). Physico-chemical properties of Loy Yang lignite dewatered by mechanical thermal expression, Fuel, 84(14), 1940-1948.

Strauß, K., Berger, S., Bergins, C. (1997). Mechanical/thermal brown coal dewatering. 20th International Mineral Processing Congress (IMPC), 75-82.

Vogt, C., Wild, T., Bergins, C., Strauß, K., Hulston, J., Chaffee, A.L. (2012). Mechanical/thermal dewatering of lignite. Part 4: Physico-chemical properties and pore structure during an acid treatment within the MTE process. Fuel, 93, 433-442.

Wheeler, R.A., Hoadley, A.F.A., Clayton S.A. (2009). Modelling the mechanical thermal expression behaviour of lignite. Fuel, 88, 1741-1751. 


\section{ANALIZA PROCESU MECHANICZNEGO ODWADNIANIA POFERMENTU}

Streszczenie. Technologie przetwarzania surowców rolniczych, jak i pozostałości produkcyjnych z przemysłu rolno-spożywczego wymagają często przeprowadzenia procesów ich odwadniania. Jednym $\mathrm{z}$ takich materiałów jest poferment tj. masa pozostała po procesie biogazyfikacji, która charakteryzuje się dużym uwodnieniem (powyżej 85\%). Celem badań było poznanie wpływu ciśnienia odwadniania na zmianę zawartości wody w pofermencie z biogazowni w Piekoszowie. Proces mechanicznego odwadniania przeprowadzono odzwierciedlając warunki pracy pras ślimakowych do odwadniania surowców roślinnych, o średnicy wewnętrznej sita $160 \mathrm{~mm}$. Poznanie wpływu ciśnienia na dynamikę spadku wilgotności surowca, pozwoli na modelowanie pracy urządzeń przemysłowych o podobnych parametrach pracy. W związku z tym przeprowadzono badania procesu odwadniania przy zastosowaniu ciśnienia w zakresie 0,58-2,91 $\mathrm{MPa}$ oraz sit szczelinowych o wielkości otworów 0,$1 ; 0,2$ oraz $0,3 \mathrm{~mm}$. Przeprowadzona analiza uzyskanych wyników wskazuje, iż efektywny proces odwadniania badanego pofermentu zachodzi przy ciśnieniu roboczym do $1,74 \mathrm{MPa}$, niezależnie od zastosowanego sita. Dalszy wzrost ciśnienia nie powoduje istotnego spadku wilgotności w badanym materiale.

Słowa kluczowe: odwadnianie mechaniczne, poferment, prasa ślimakowa, wilgotność 